\title{
SUBSIDENCE HAZARDS CAUSED BY THE DISSOLUTION OF PERMIAN GYPSUM IN ENGLAND: GEOLOGY, INVESTIGATION AND REMEDIATION
}

\author{
A H Cooper, British Geological Survey, \\ Kingsley Dunham Centre, Keyworth, Nottingham NG12 5GG.
}

This is a recompiled version of the final draft of the published paper, it is presented with coloured versions of the figures and may differ slighly from the published edited version. Please respect copyright of BGS/NERC and refer to the final published version if you wish to quote the work.

Published as:

Cooper, AH. 1998. Subsidence hazards caused by the dissolution of Permian gypsum in England: geology, investigation and remediation. 265-275 in: Geohazards in engineering geology, Maund, JG, Eddleston, M (eds.). Geological Society of London. Special Publications in Engineering Geology, 15.

\begin{abstract}
About every three years natural catastrophic subsidence, caused by gypsum dissolution, occurs in the vicinity of Ripon, North Yorkshire, England. Holes up to $35 \mathrm{~m}$ across and $20 \mathrm{~m}$ deep have appeared without warning. In the past 150 years, 30 major collapses have occurred, and in the last ten years the resulting damage to property is estimated at about $£ 1,000,000$. Subsidence, associated with the collapse of caves resulting from gypsum dissolution in the Permian rocks of eastern England, occurs in a belt about $3 \mathrm{~km}$ wide and over $100 \mathrm{~km}$ long. Gypsum $\left(\mathrm{CaSO}_{4} \cdot 2 \mathrm{H}_{2} \mathrm{O}\right)$ dissolves rapidly in flowing water and the cave systems responsible for the subsidence are constantly enlarging, causing a continuing subsidence problem.

Difficult ground conditions are associated with caves, subsidence breccia pipes (collapsed areas of brecciated and foundered material), crown holes and post-subsidence fill deposits. Site investigation methods that have been used to define and examine the subsidence features include microgravity and resistivity geophysical techniques, plus more conventional investigation by drilling and probing. Remedial measures are difficult, and both grouting and deep piling are not generally practical. In more recent times careful attention has been paid to the location fo development and the construction of low-weight structures with spread foundations designed to span any subsidence features that may potentially develop.
\end{abstract}

\section{INTRODUCTION}

Gypsum $\left(\mathrm{CaSO}_{4} \cdot 2 \mathrm{H}_{2} \mathrm{O}\right)$ is widespread in the Permian and Triassic strata of England, but because of its very soluble nature it generally occurs only in low ground with an extensive cover of Quaternary superficial deposits; natural exposures of gypsum are rare. Its presence, especially in the Permian strata, is often indicated by natural catastrophic subsidence and existing subsidence features. In the urban area of Ripon, North Yorkshire, the catastrophic subsidence has caused about $£ 1,000,000$ worth of damage in the last 10 years and has generated problems for both planners and engineers. An understanding of the gypsum dissolution mechanisms and the geological controls of the subsidence are crucial for effective planning control and engineering practice. The problem is also of interest to property owners and insurance organisations. 


\section{GYPSUM DISSOLUTION AND SUBSIDENCE HISTORY}

Gypsum dissolves rapidly; a process illustrated by the dissolution of a gypsum cliff adjacent to the River Ure [NGR SE 307 753], 5 km north of Ripon (James et al.,1981). At this locality a block of gypsum, amounting to approximately 9 cubic metres, was dissolved, in only 18 months, by a river water flow velocity of about $1 \mathrm{~m}$ per second. Over the next ten years the new gypsum face was undercut by a further $6 \mathrm{~m}$, collapsing again in 1989 (James, 1992). Subterranean gypsum dissolution will form caves (Ryder \& Cooper, 1993) and fast flowing water in them may remove up to 0.5 to $1 \mathrm{~m}$ of gypsum per annum from the cave walls.

In England, Ripon suffers the worst subsidence caused by gypsum dissolution. Here at least 30 major collapses have occurred in the past 150 years and further collapses might be expected every two to three years (Cooper, 1986, 1988, 1989, 1995). The subsidence hollows are commonly $10-30 \mathrm{~m}$ in diameter and reach $20 \mathrm{~m}$ in depth; east of the city they attain dimensions of up to $80 \mathrm{~m}$ diameter and $30 \mathrm{~m}$ deep. Numerous sags and small collapses on farmland go undetected, but careful analysis of historical levelling data indicates some areas of general ground lowering (P.R.Hogbin, 1994, unpublished MSc thesis, Imperial College, University of London). Many of the subsidence features at Ripon are arranged in a reticulate pattern (Figure 1) related to the intersections of the joint systems in the rock (Cooper, 1986).

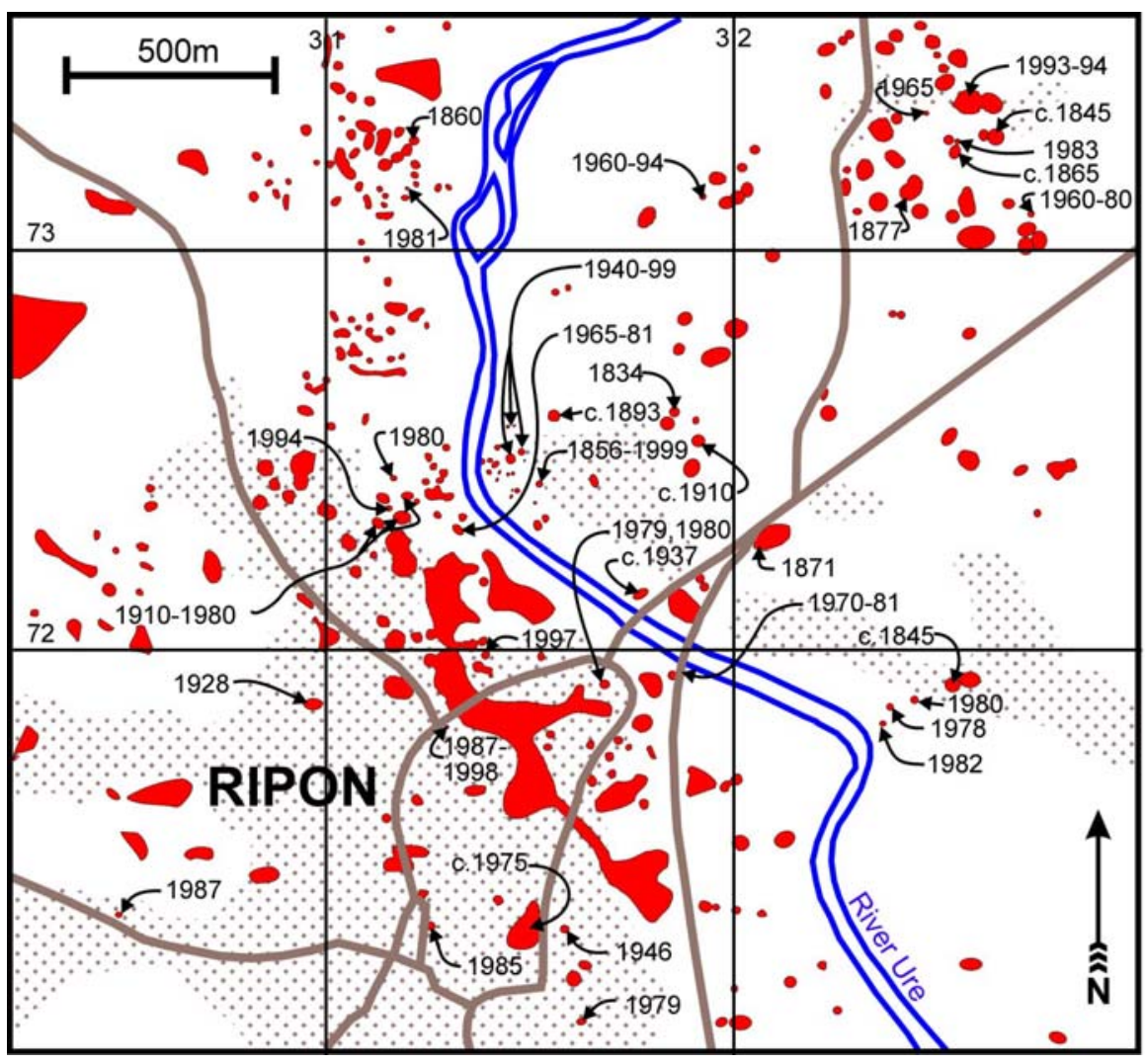

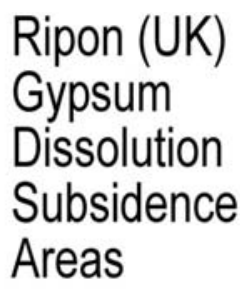

Natural dissolution of gypsum results in a cave system which is continually and rapidly enlarging. Collapse into the caves causes severe catastrophic subsidence at the surface.

The natural subsidence is a major constraint to development in the area.

Subsidence hollows with dates of subsidence Built up areas

FIGURE 1. The distribution and ages of subsidence hollows recorded in the vicinity of Ripon, North Yorkshire; built up area shaded, subsidence hollows shown in red.

\section{GEOLOGY}

The strata of the subsidence belt (Figure 2) are mainly of Permian age. They comprise a lower carbonate (Cadeby Formation - 60 m thick) overlain by the Edlington Formation which consists 
of up to $40 \mathrm{~m}$ of gypsum overlain by $10 \mathrm{~m}$ of gypsiferous mudstone and mudstone. This is followed by another carbonate (Brotherton Formation - $12 \mathrm{~m}$ thick) overlain by up to $10 \mathrm{~m}$ of gypsum, then about $12 \mathrm{~m}$ of mudstone belonging to the Roxby Formation. The Cadeby and Brotherton Formations are both aquifers. The succession is capped by the red sandstone of the Triassic Sherwood Sandstone Group, the major regional aquifer, which attains $300 \mathrm{~m}$ in thickness. The rocks dip eastwards at about 2-3 degrees and are partially concealed by Quaternary superficial deposits.

At Ripon the bedrock is cut through by a deep, largely buried, valley approximately following the course of the River Ure, and partially filled with up to $22 \mathrm{~m}$ of Devensian glacial and postglacial deposits (Powell, et al., 1992; Cooper and Burgess, 1993). The buried valley intersects the carbonate and gypsum units creating a hydrological pathway from the bedrock to the river. Considerable groundwater flow occurs along this pathway and artesian water emanates from the Permian strata as springs which issue along the valley sides and up through the Ure valley gravels. Artesian water, with a head above that of the river, has been encountered in some boreholes. Much of this water is nearly saturated with, or rich in dissolved calcium sulphate resulting from the dissolution of gypsum.

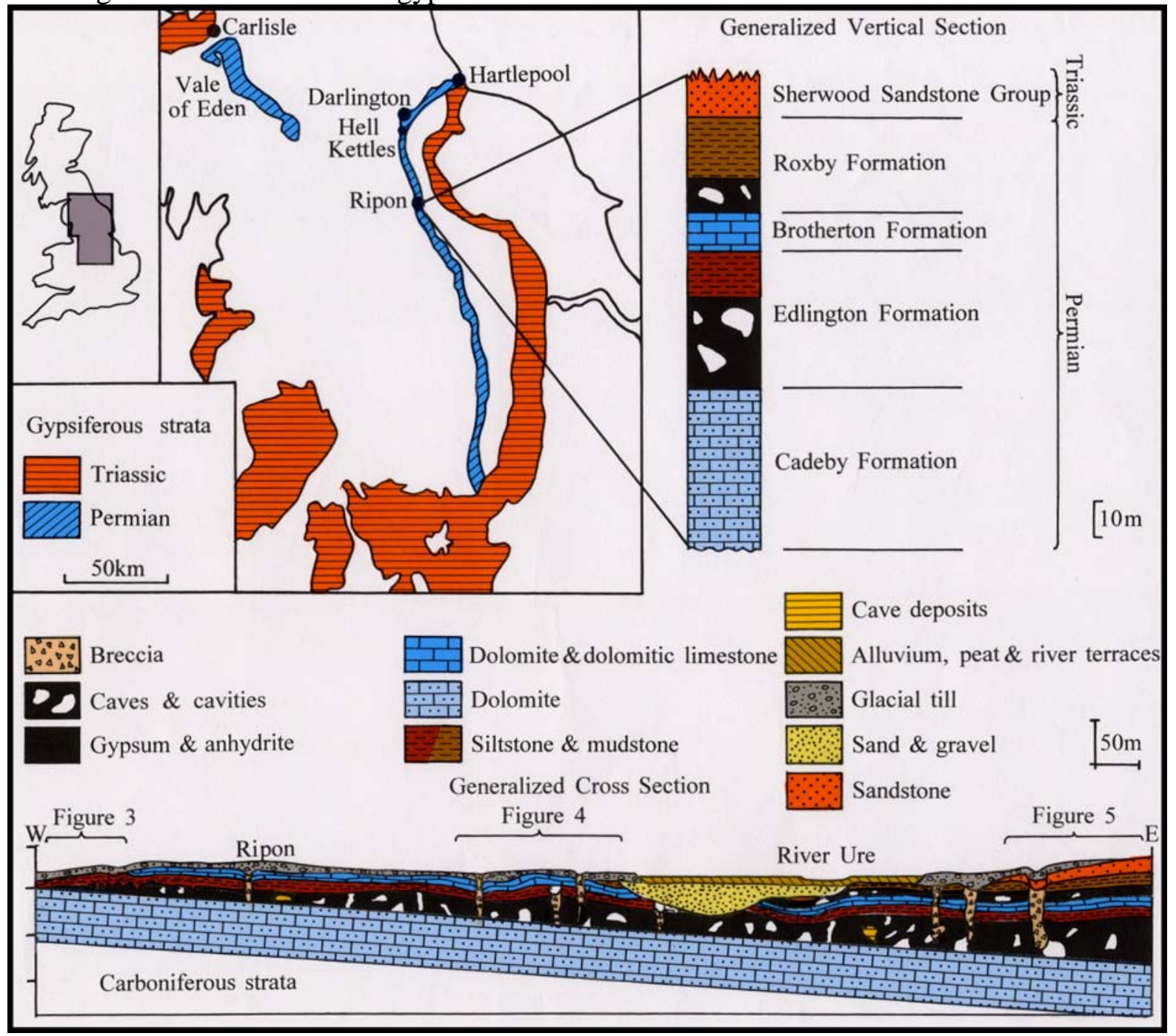

FIGURE 2. Distribution of gypsiferous strata in northern England and the Permian sequence in Yorkshire (inset map). The sketch geological cross-section illustrates the geology around Ripon. It shows caves in the gypsum sequence and their upwards propagation as breccia pipes. The 
legend is also that for Figures 3 and 4, whose approximate positions are shown on the crosssection.

The greatest concentration of active subsidence hollows coincides with the areas marginal to the buried valley. Much of the sand and gravel partially filling the valley is cemented with calcareous tufa deposited from the groundwater which is also rich in dissolved carbonate (Cooper, 1988). Subsidence is more extensive than it appears on the floodplain of the River Ure, because many of the subsidence features are infilled by overbank deposits.

Two factors delineate the subsidence belt. Westwards, the limit is the base of the lowest gypsum unit, which coincides with the base of the Edlington Formation, eastwards it is bounded by the down-dip transition from gypsum to anhydrite (Cooper, 1986). The gypsum belt extends from Hartlepool, through Darlington and Ripon to near Doncaster. It has a maximum width of about 3 $\mathrm{km}$ and extends to a depth of around $100 \mathrm{~m}$. From west to east across the belt the gypsum units show a progression from complete dissolution of gypsum, through buried pinnacled gypsum karst, to gypsum with caves and subsidence features, then finally to anhydrite (Figure 2).

\section{VARIATION OF THE SUBSIDENCE FEATURES AT RIPON}

The localised character of the subsidence features is dependent on the underlying geological sequence and the superficial deposits at the surface. In the west of Ripon, only one sequence of gypsum is dissolving, in the east two are dissolving (Figures 2 to 5). In some places competent sandstone or limestone strata are present at the surface, in others soft mudstone is present. The situation is further complicated by differences in the Quaternary superficial deposits which vary from thick valley-fill deposits to a blanket covering of glacial till (Figure 2). Because of these variables, and as an aid to site investigation and subsequent design work, the nature of the geology and subsidence features from west to east across the area are described below.

Cadeby Formation. In the west of the area the Cadeby Formation, up to $60 \mathrm{~m}$ thick, forms the major escarpment of the Permian sequence. It is a local aquifer and yields water under artesian conditions which cause dissolution of the gypsum that lies immediately above it. Although the Cadeby Formation mainly consists of only moderately soluble dolomite, it does have caves and karst features in a few areas, such as near Doncaster, Wetherby, Knaresborough and the equivalent rocks in Sunderland. Generally it does not constitute a great geological hazard. However, in places where it has been dedolomitised by flowing water, especially near the top of the formation at its contact with the overlying gypsum, it may present a considerable hazard. The end product of dedolomitisation may be a porous calcitic mush of low bearing strength that disintegrates to a 'sand' and this localised potential lack of strength should be considered if the rock is intended for founding piles.

Edlington Formation and associated gypsum. The main gypsum sequence in the Edlington Formation of Yorkshire rests immediately above the dolomite of the Cadeby Formation (Figures 2 to 5). At Ripon it comprises up to $40 \mathrm{~m}$ of massive gypsum overlain by about $10 \mathrm{~m}$ of redbrown calcareous and gypsiferous mudstone. In the west at its feather edge the gypsum dissolves to form a pinnacled gypsum karst into which the overlying mudstones and Quaternary deposits founder (A in Figure 3). From borehole information, and by comparison with the pinnacled gypsum karst seen in the Vale of Eden (Ryder and Cooper, 1993), it can be expected that within this belt the gypsum pinnacles may have vertical sides, or be undercut to become cavernous ( $\mathrm{E}$ in Figure 3). The pinnacles and dissolution furrows may be many metres in height. 
The lower part of the gypsum in contact with the underlying Cadeby Formation may also be considerably dissolved and cavernous ( $\mathrm{C}$ in Figure 3). Throughout much of the Ripon area the pinnacled gypsum karst is concealed beneath $10-20 \mathrm{~m}$ of collapsed mudstone and superficial deposits; these will not bridge large cavities and the size of the collapses will be limited by the bridging capabilities of the massive gypsum. In general, individual subsidence depressions less than $10 \mathrm{~m}$ across occur within this belt of rock (C and $\mathrm{G}$ in Figure 3), but in some areas they are amalgamated into larger subsidence areas (B in Figure 3). Some of the subsidence hollows will be the result of sagging and flow of the overlying deposits ( $\mathrm{C}$ in Figure 3), while others will be underlain by breccia pipes, possibly penetrating to the Cadeby Formation ( $G$ in Figure 3). Caves may be expected anywhere within the gypsum, and caves partially filled in with laminated clays, deposited from material held in suspension by cave waters, and collapse breccias have been recorded. Within this area and in many of the areas to the east fossil subsidence features predating the Quaternary glaciation may also be present. Thus subsidence hollows completely filled with glacial till, or laminated clay glacial deposits beneath the till, may occur (D in Figure $3)$.

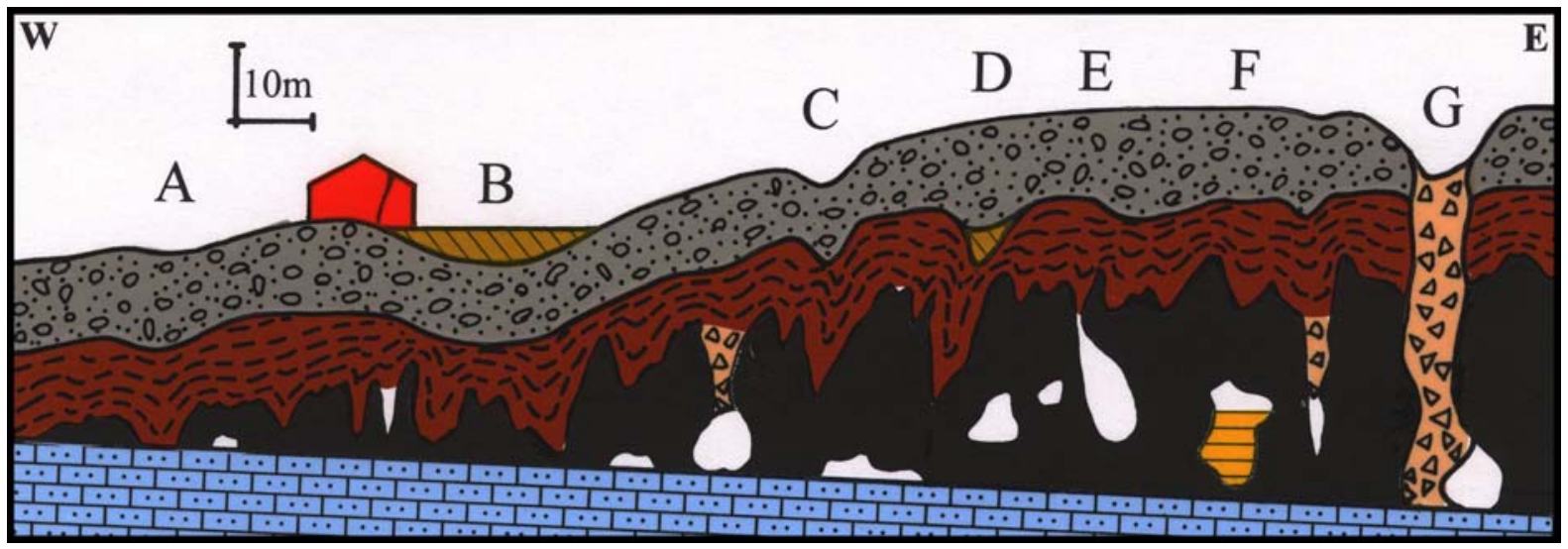

FIGURE 3. Stylised cross-section through gypsum dissolution subsidence features in the west of the Ripon subsidence belt. See Figure 2 for legend and text above for explanation.

Brotherton Formation. Above the Edlington Formation, the Brotherton Formation comprises thin-bedded dolomitic limestone 8 to $14 \mathrm{~m}$ thick (Figures $2 \& 4$ ). It is an aquifer that feeds water down-dip to dissolve the overlying gypsum in the Roxby Formation. The Brotherton Formation can bridge considerable cavities that emanate upwards from the underlying gypsum (E in Figure 4). However, when it fails it can do so catastrophically, producing hollows up to $20 \mathrm{~m}$ across such as those at Magdalens Road, Ripon [SE 3170 7192](1979 \& 1980, Cooper 1986 Figure 3b), and Nunwick [SE 3184 7473] (Cooper 1986;C in Figure 4). Since up to 40m of gypsum could be dissolved from beneath it (B in Figure 4), the whole of the Brotherton Formation outcrop has a potential for subsidence. At Ripon Golf Course [SE 312 732], the closely spaced subsidence hollows form a reticulate pattern of conical depressions probably formed over joint intersections in the gypsum. In the topographically lower parts of Ripon, such as Princess Road [SE 315718 ] and Dallamires Lane [SE 318 703] similar groupings of intersecting conical subsidence hollows have become infilled with thick peat and clay deposits (A in Figure 4). Attempts to overcome such severe foundation conditions have been made by piling. However, the piles terminate in the glacial till deposits and only partially cope with the problems of compressible peat and soft deposits which commonly suffer considerable further consolidation after construction. This type of foundation design does not address the problem of further gypsum dissolution and collapse at depth. 
The Brotherton Formation limestones can bridge fairly large cavities and some of the gypsum caves below it have not collapsed. Instead they have become partially choked with cave deposits including laminated clay with subordinate peat and gravel washed into the cave system (D in Figure 4). Thus it is possible to have a complex Quaternary sequence, at depth, underground beneath undisturbed surface geology. Breccia pipes penetrate the Brotherton Formation and include unconsolidated foundered material (Patterson et al., 1995), either Quaternary deposits or solid strata. In these pipes foundered areas of brecciated red-brown mudstone (derived from the Roxby Formation) or red sandstone (derived from the Sherwood Sandstone Group) commonly occur. Some of these collapse structures must be ancient because the stratigraphically younger formations, preserved in the pipes, have now been removed by erosion from the local area. Similar features penetrate the Brotherton Formation near Leeds at Sherburn in Elmet (Smith, 1972). On the floodplain of the River Ure subsidence hollows filled with unconsolidated organicrich sand and silt occur. Some of these are further complicated by the presence of tufa-cemented deposits precipitated from artesian groundwater rich in dissolved carbonate.

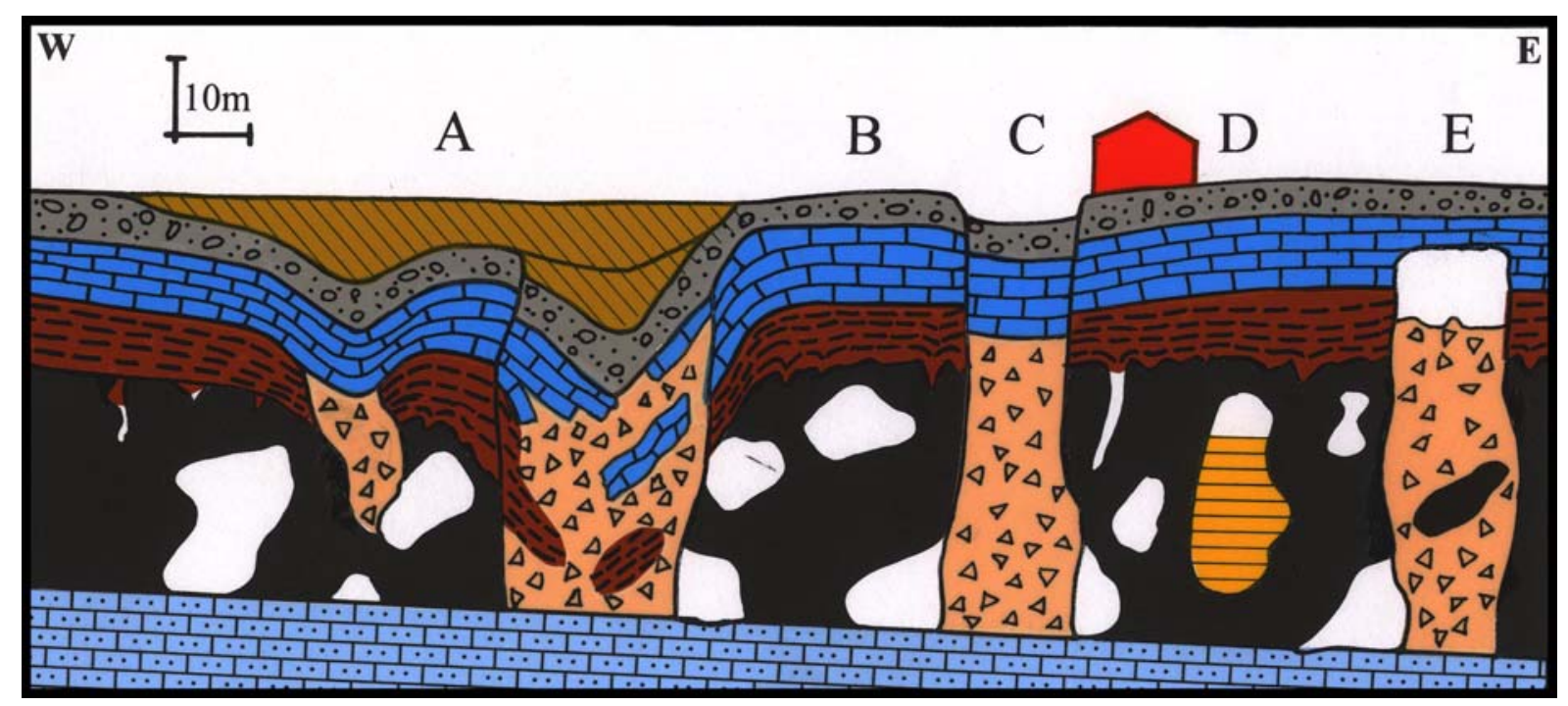

FIGURE 4. Stylised cross-section through gypsum dissolution subsidence features in the centre of the Ripon subsidence belt. See figure 2 for legend and text above for explanation.

Roxby Formation and associated gypsum. Above the Brotherton Formation, the Roxby Formation includes up to $10 \mathrm{~m}$ of gypsum overlain by about $10 \mathrm{~m}$ of gypsiferous and calcareous mudstone. Areas where the Roxby Formation is at rockhead have two potentially unstable sequences of gypsum. The complicated gypsum cave systems are linked by near-vertical subsidence and breccia pipes which unite the hydrological regimes of both the two dolomitic formations and the two gypsum sequences. Subsidence hollows developed on the Roxby Formation may reach about $20 \mathrm{~m}$ across, and are concentrated along the margins of the River Ure buried valley where artesian water escapes from the Permian sequence. Some hollows formed over this formation, such as the one developed at Sharow in 1982 [SE 3238 7182] (Cooper, 1986, Figure 3b), formed catastrophically and are deep-seated. The gypsum sequence in the Roxby Formation will be karstified, at rockhead, with pinnacles and caves similar to those in the Edlington Formation gypsum.

Sherwood Sandstone Group. The lower part of the Sherwood Sandstone Group is affected by 
subsidence. Up to $50 \mathrm{~m}$ total thickness of gypsum can be removed from beneath this Group up to $1-1.5 \mathrm{~km}$ from its western boundary. Spectacular subsidence hollows and amalgamated hollows up to $80 \mathrm{~m}$ across and $30 \mathrm{~m}$ deep occur near Hutton Conyers [SE 3259 7305]. Active subsidence hollows in this belt reach $40 \mathrm{~m}$ across, such as the one at Hutton Conyers that severely damaged a house in 1993 and 1994 [SE 3257 7339] (A in Figure 5). The Sherwood Sandstone can bridge large cavities, but may fail catastrophically resulting in large cylindrical subsidence pipes such as the one that developed near Ripon Railway Station in 1834 (C in Figure 5; Figure 3 in Cooper, 1989). Where thick drift deposits overlie the sandstone the subsidence hollows form close groupings of conical-shaped depressions; good examples being Corkscrew Pits [SE 3200 7315] and near Hutton Conyers [SE 3273 7305] (D in Figure 5). The breccia pipes associated with the subsidence can propagate up from the lower parts of the Edlington Formation which may lie as much as $100 \mathrm{~m}$ below surface. Like the more western areas, great variations in caves and cave deposits ( $\mathrm{B}$ in Figure 5) can occur beneath the area. The great depth and complexity of the subsidence problem makes detailed site investigation expensive and difficult.

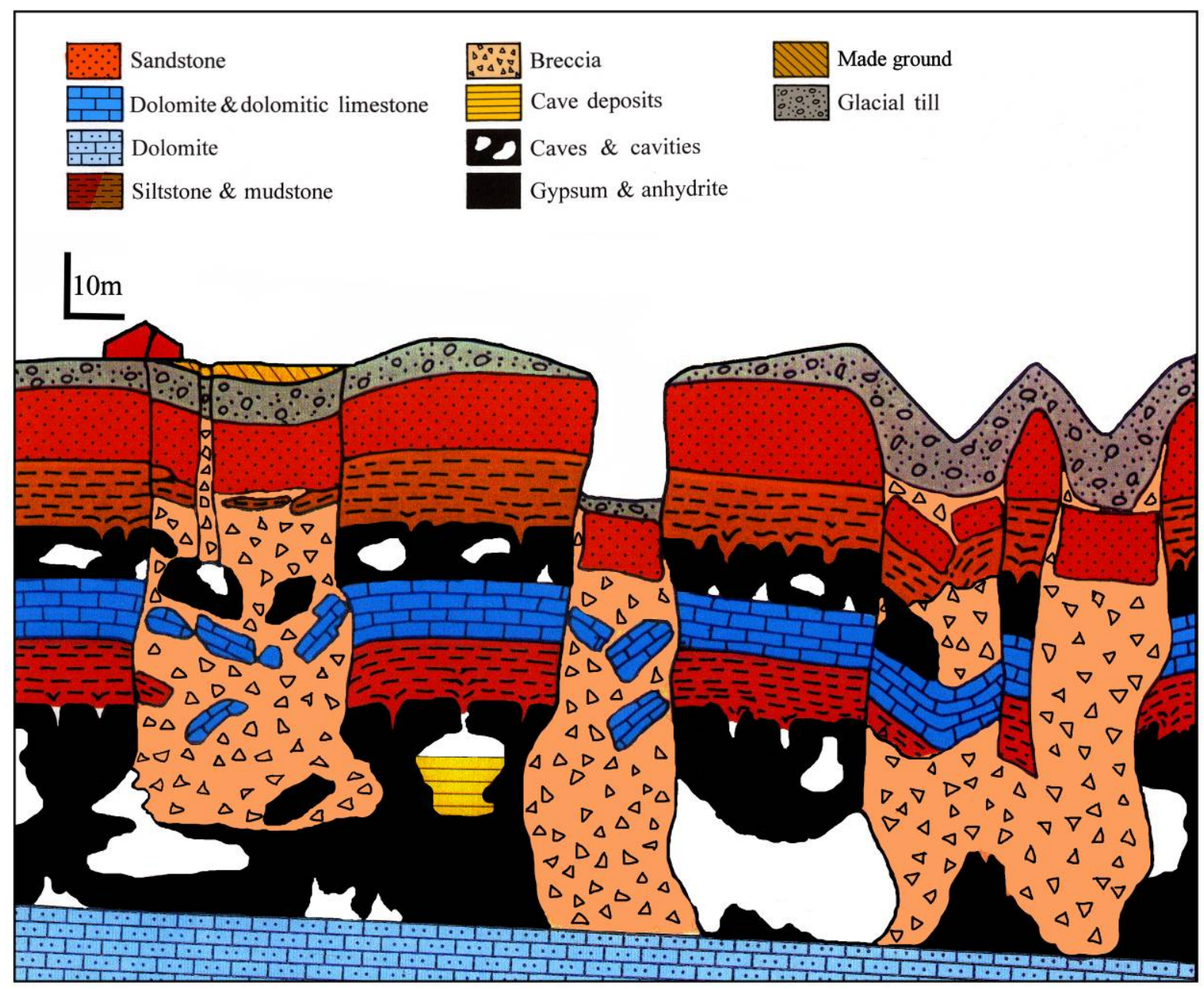

FIGURE 5. Stylised cross-section through gypsum dissolution subsidence features in the east of the Ripon subsidence belt. See text above for explanation. 


\section{GYPSUM DISSOLUTION AND SUBSIDENCE AT DARLINGTON}

The subsidence-prone belt extends from Ripon northwards to Darlington and Hartlepool (Figure 2), where the sequence is similar to that at Ripon, but the carbonate formations have different names. Around Darlington up to $40 \mathrm{~m}$ of gypsum is present in the Edlington Formation and up to $7 \mathrm{~m}$ in the Roxby Formation. Two types of subsidence occur in this northern area: (a) catastrophic collapse similar to that at Ripon and (b) more widespread settlement; the distinction between the two types is controlled by the hydrogeology and the thickness and lithology of the overlying glacial deposits.

South of Darlington at Hells Kettles, catastrophic collapse occurred in 1179. Four subsidence hollows up to $35 \mathrm{~m}$ in diameter and $6 \mathrm{~m}$ deep were formerly present (Longstaffe, 1854), but one of these is now filled in. These hollows are very similar to those at Ripon (Cooper, 1986, 1989). Artesian water emanates from Hell Kettles and from sulphate-rich springs nearby at Croft. Like Ripon, the sequence here dips gently eastwards and the outcrop of the carbonate formations is a groundwater recharge area. The ground water moves down-dip to the low ground of the wide, partly-buried, valley of the River Tees. The subsidence appears to be associated with the margins of the buried valley, as at Ripon.

The southern half of Darlington has suffered subsidence related to gypsum dissolution. Here the subsidence has been prolonged, less severe (generally less than $0.3 \mathrm{~m}$ ), and spread over subsidence depressions up to several hundred metres in diameter. Local boreholes have proved thick gypsiferous strata similar to those at Ripon, and cavities were encountered in one borehole. The bedrock surface forms a very broad valley filled with around $50 \mathrm{~m}$ of glacial and postglacial deposits which include water-saturated sand and plastic laminated clays. As the gypsum dissolution proceeds, it appears that the overlying water-saturated sand flows into the gypsum cavities. Support is removed over wide areas causing broad subsidence depressions at the surface. The subsidence belt continues to the north-east of Darlington, extending to the coast at Hartlepool where thick deposits of anhydrite underlie part of the town.

\section{INVESTIGATION OF GYPSUM SUBSIDENCE-PRONE AREAS FOR DEVELOPMENT}

The depth of the gypsum sequences over many of the areas in question, and the evolving nature of the subsidence phenomenon makes site investigation and remediation difficult. Generally, only shallow site investigations have been undertaken over the gypsum subsidence belt. Detailed investigations, for modern developments, are now demanded by the planning authorities. If sites are investigated by boreholes alone, the size of the subsidence features demand closely spaced boreholes (at around $10 \mathrm{~m}$ intervals or less) drilled to the base of the gypsum; commonly this is 40-60 m deep under the city of Ripon. For such investigations it is important to core the solid strata and to have it logged by a geologist competent in identifying gypsum in all its forms. In the bulk of archival site investigation data, gypsum (except for satin spar) is usually identified as limestone. A potential problem with site investigation by drilling is the likelihood of triggering a subsidence event in unstable ground, either by vibration or circulation of drilling fluids; this has not happened yet, but should be considered when planning site investigations, the safety of the drill crew, and the associated insurance cover.

An alternative investigation technique is to use geophysics as part of a phased drilling and probing investigation. At Ripon, microgravity has successfully been used to delineate anomalies 
that have subsequently been drilled (Patterson et al., 1995). Computer-based modelling and field investigations (D.M.McCann pers. comm., 1992) show that microgravity can delineate breccia pipes and large cavities that breach, or come near to, the surface. However, even large caves, at depth, are difficult to image and edge effects of superficial deposits can partially conceal anomalies. At Ripon, subsidence features have also been investigated using ground conductivity electromagnetic and galvanic resistivity methods (gradient array; BGS RESCAN technique) (J.P.Busby pers. comm.,1992). These have proved a faster survey method than microgravity and have shown many anomalies, but few have yet

been drilled to check the information and electrical methods are difficult to use in built up areas.

\section{EVALUATION OF POSSIBLE REMEDIAL MEASURES}

The dates and locations recorded for the historically recent subsidence events suggest concentration of water flow in the cave systems along certain specific paths (Figure 1). The close grouping of subsidence hollows suggests that once a collapse has occurred the cave partially chokes and the dissolution continues in the adjacent strata. This commonly produces linear belts of subsidence related to the joint pattern. It also means that localities adjacent to, or in line with, existing subsidence hollows are probably more at risk from future subsidence.

Engineers have suggested that grouting can be used to stabilise gypsum caves; this technique has been used in the Palaeogene gypsum of the Paris area (Toulemont, 1984), but the long-term outcome of the work is not reported. In general, grouting of a gypsum cave system is not advisable. Unless the caves are small, proved to be abandoned and completely dry, filling them with grout could alter the groundwater regime. This could cause dissolution in the adjacent ground in the same way that natural collapse may block a cave system and through diversion of water channels cause dissolution nearby. There could also be problems caused by locally raising the local water table which could trigger off subsidence. If a dry abandoned cave system was to be grouted, sulphate-resistant cement would have to be used.

Conventional piling, as already practised at Ripon, is also problematical; piles through disturbed and unconsolidated deposits may achieve the required bearing strength on the base of the pile in either the glacial deposits or the bedrock below. However, since the bedrock contains gypsum beds, caverns might be present and these might propagate upwards thereby destabilising the piled structures. It might be feasible to pile through the gypsum sequences, using bored piles, to the carbonate formation below, if the latter is not dedolomitised, but this could involve piling to depths of about $80 \mathrm{~m}$ to the east of the city. The use of sulphate-resistant cement would add to the cost and there is a danger that dissolution and collapse of the strata could place additional loads on the piles. This would necessitate the use of piles with a negative skin friction. Because of the prohibitive costs and likely difficulties associated with piling it is largely impractical except in the west of the subsidence belt, or for all but the most expensive and sensitive structures.

An alternative approach used in Ripon (Patterson et al., 1995) has been to delineate and avoid any subsidence hollows and breccia pipes. The constructions have then been placed within the site over the best ground conditions and designed to have minimal impact on the subsurface. They have also been designed to span any subsidence features that may potentially develop. This sort of approach can only be undertaken after extensive site investigation by engineering geologists working in close liaison with foundation engineers. 


\section{ACKNOWLEDGEMENTS}

The help of numerous colleagues is acknowledged especially Drs Dave McCann and John Busby for information about geophysical techniques and Mr Martin Culshaw for engineering geology. Dr Peter Allen, Mr Tim Charsley, Mr Martin Culshaw \& Dr John Powell are thanked for critically reviewing the manuscript. The geological survey of the Ripon area was supported by the Department of the Environment. A recent resurvey updating the information was supported by the Department of the Environment in association with Travers Morgan Ltd; Dr Alan Thomson of Travers Morgan Ltd is thanked for useful discussion. This paper is published with permission of the Director, British Geological Survey (N.E.R.C.).

\section{REFERENCES}

Cooper, A.H. 1986. Foundered strata and subsidence resulting from the dissolution of Permian gypsum in the Ripon and Bedale areas, North Yorkshire. 127-139 in Harwood, G M and Smith, D B (Editors). The English Zechstein and related topics. Geological Society of London, Special Publication. No. 22.

Cooper, A.H. 1988. Subsidence resulting from the dissolution of Permian gypsum in the Ripon area; its relevance to mining and water abstraction. 387-390 in Bell, F G, Culshaw, M G, Cripps, J C and Lovell, M A (Editors) Engineering Geology of Underground Movements. Geological Society of London, Engineering Geology Special Publication No.5.

Cooper, A.H. 1989. Airborne multispectral scanning of subsidence caused by Permian gypsum dissolution at Ripon, North Yorkshire. Quarterly Journal of Engineering Geology (London), 22, 219-229.

Cooper, A.H. 1995. Subsidence hazards due to the dissolution of Permian gypsum in England: investigation and remediation. 23-29 in Beck, F.B. (ed.) Karst Geohazards: engineering and environmental problems in karst terrane. Proceedings of the fifth multidiciplinary conference on sinkholes and the engineering and environmental impacts of karst Gatlinburg/Tennessee/2-5 April 1995. 581pp. A.A.Balkema, Rotterdam.

Cooper, A H and Burgess, I C. 1993 Geology of the country around Harrogate. Memoir of the British Geological Survey, Sheet 62 (England and Wales).

James, A.N., 1992. Soluble materials in civil engineering. Ellis Horwood Ltd, England. 433 pp.

James, A.N., Cooper, A.H. and Holliday, D.W. 1981. Solution of the gypsum cliff (Permian Middle Marl) by the River Ure at Ripon Parks, North Yorkshire. Proceedings of the Yorkshire Geological Society, 43, 433-450.

Longstaffe, W.H.D. 1854. The History and antiquities of the parish of Darlington. The proprietors of the Darlington and Stockton Times, London: republished by Patrick \& Shotton

Patterson, D, Davey, J C, and Cooper, A H. 1995. The application of microgravity geophysics in a phased investigation of dissolution subsidence at Ripon, Yorkshire. Quarterly Journal of Engineering Geology (London), 28, 83-94. 
Powell, J H, Cooper, A H and Benfield, A C. 1992. Geology of the country around Thirsk. Memoir of the British Geological Survey, Sheet 52 (England and Wales).

Ryder, P F, and Cooper, A H. 1993. A cave system in Permian gypsum at Houtsay Quarry, Newbiggin, Cumbria, England. Cave Science. 20, 23-28.

Smith, D.B. 1972. Foundered strata, collapse breccias and subsidence features of the English Zechstein. 255-269 in Richter-Bernburg, G. (Editor). Geology of saline deposits. Proc. Hanover Symposium, 1968. (Earth Sciences, 7). (Paris: U.N.E.S.C.O.) 316p.

Toulemont, M. 1984. Le karst gypseux du Lutétien supérieur de la région parisienne. Charactéristiques et impact sur le milieu urbain. Revue de Géologie Dynamique et de Géographie Physique. 25, 213-228. 